\title{
МЕТАФОРИЗАЦІЯ ЯВИЩ ПРИРОДИ В ПОЕТИЧНІЙ МОВОТВОРЧОСТІ БОРИСА ОЛІЙНИКА
}

\author{
ОЛЬГА ДІБРОВА \\ Харківський національний педагогічний університет імені Г. С. Сковороди, \\ Харків - Україна \\ METAFORYZACJA ZJAWISK PRZYRODY W MOWIE \\ POETYCKIEJ BORYSA OLIJNYKA \\ OLGA DIBROWA \\ Charkowski Narodowy Uniwersytet Pedagogiczny im. H. Skoworody, \\ Charków - Ukraina
}

STRESZCZENIE. Artykuł poświęcony jest analizie zjawisk przyrody, które wpłynęły na kształtowanie języka poetyckiego utworów Borysa Olijnyka. Wyróżniono znaczenie symboliczne zjawisk przyrody, zbadano specyfikę ich funkcjonowania w tekstach poetyckich ukraińskiego pisarza. Ponadto ukazano cechy charakterystyczne metafor wykorzystanych w utworach Borysa Olijnyka, poczyniono próbę interpretacji lingwistycznej jednostek metaforycznych dla oznaczania zjawisk przyrody.

\section{METAPHORIZATION OF NATURAL PHENOMENA IN BORYS OLIYNYK'S POETIC LANGUAGE CREATIVITY}

\section{OLGA DIBROVA}

\section{H. S. Skovoroda Kharkiv National Pedagogical University, Kharkiv — Ukraine}

ABSTRACT. The paper is devoted to the analysis of natural phenomena involved in the formation of verbal and poetic images. The author singles out symbolic meanings of natural phenomena, investigates the specificity of their image-defining features in Borys Oliynyk's poetic texts. The specific features of Borys Oliynyk's metaphors are outlined; an attempt of linguistic metaphorical interpretation of units denoting natural phenomena is made.

$\mathrm{H}$ а початку 60-х років XX ст. услід за Ліною Костенко та Дмитром Павличком на творчу ниву вийшли такі письменники, як Іван Драч, Василь Симоненко, Микола Вінграновський, Володимир Коломієць, Ірина Жиленко та інші. Цих поетів прийнято називати шістдесятниками. До цього покоління належить і поет Борис Олійник.

Творче зростання Б. Олійника відбувалося досить стрімко. Родом із країв полтавських - може сказати про себе поет з гордістю. Звідти він, де „чорнозем плодючий, наче жінка" золоті обжинки завжди напохваті зі сміху литий серп” (т. 4, с. 18).

Поезія Б. Олійника є оригінальною в багатьох своїх аспектах — в образотворчості, використанні розмаїття стилістичних фігур та тропів. Та чи не найголовнішою ознакою творів поета $є$ лексичний зріз текстів. Словесно-художня

${ }^{1}$ Б. І . О л і й н и к, Вибрані твори в 6 m., Київ 2007, т. 4, с. 18 - далі подаємо поклики на це видання в круглих дужках, зазначаючи конкретний том і сторінку. 
реалізація автора широко презентує багатство української мови, а також уміння письменника оперувати словами. Серед лексичних засобів вираження авторського естетичного погляду на довкілля особливе місце належить явищам природи.

Актуальність роботи зумовлена посиленням інтересу сучасної української лінгвістики до когнітивного аспекту дослідження мови, з'ясування того, яким чином мова інтерпретує світ, реалізуючи ментальні особливості нації та систему іiі цінностей. Відповідно до цього, важливим і необхідним є завдання скласти уявлення про МКС явищ природи.

Одним із засобів розвитку й збагачення семантики і функцій слів, без утворення нових, є метафоризація мови, вживання слів у непрямому значенні у функції метафори. Процес метафоризації мови 3 поширенням семантики й стилістичної функції слів — це давній, праісторичний процес. Унаслідок цього багато слів сучасної мови набули різних значень.

Дослідженню метафоризації присвячено чимало праць лінгвістів, літературознавців, філософів, психологів, але проблема метафоризації залишається надзвичайно складною, адже йдеться про процеси мислення, в яких породжується знання про світ. Метафоризація — це не лише вживання одного слова замість іншого: вона утворює новий зміст, що з'являється внаслідок дії складних когнітивних механізмів.

Метафору визначають як „семантичний процес, при якому форма мовної одиниці або оформлення мовної категорії переноситься з одного об'єкта позначення на інший на основі певної подібності між цими об'єктами при відображенні в свідомості мовця"2. Лінгвістична думка накопичила чималий досвід в осмисленні метафори. Основи вивчення метафори як мовного засобу, що відображає взаємозв'язок мови і світу, закладені О. Потебнею й розвинені Р. Будаговим, Л. Виготським, В. Виноградовим, Д. Шмельовим та ін. У сучасному мовознавстві цю проблему досліджують Ю. Апресян, Н. Арутюнова, Г. Колшанський, В. Телія, зокрема в україністиці аналіз метафоричної системи представлений у працях І. Білодіда, О. Варинської, С. Срмоленко, Т. Космеди, В. Калашника, Л. Лисиченко, О. Маленко, Л. Мацько, Л. Пустовіт, О. Селіванової, Г. Сюти, Л. Шевченко та ін.

Явища природи в мовно-поетичній площині Б. Олійника досі не були об'єктом грунтовних досліджень, що мають відповідне значення для розвитку антропоцентричної парадигми сучасного мовознавства. Явища природи репрезентують зміни, що відбуваються в природі. Традиція їх метафоризації прийшла в поезію з міфології, тому більшість метафор із реципієнтними зонами “явища природи” основана на архетипах. Реципієнтними зонами таких метафор найчастіше були вітер, сніг, темінь, завірюха, туман, дощ, хмари, а також іній, райдуга, роса, град, грім та посуха. Висока частотність використання явищ природи в поезіях свідчить про важливість їх у житті людини.

Bimep є однією з основних реципієнтних зон метафоризаційних процесів у художньо-поетичному наповненні поетичних текстів Б. Олійника. Bimep всемогутня сила, справжній володар, непідвладний часові. Він здатен бути скрізь, він стає свідком людського щастя та горя, перемоги та поразки. Вітер може підняти бурю на морі, примусити людину змінити свої плани. Метафори, що його вербалізують, різнопланові, але найбільше виявляється аналогізація ві-

${ }^{2}$ Украӥнська мова: Еничиклопедія, редкол.: В. М. Русанівський, О. О. Тараненко та ін., Київ 2000, с. 334. 
тру з людиною. „Українська поезія XX ст. репрезентує нові ускладнені контексти, в яких завдяки динамічній ознаці персоніфікується природна стихія вітру"з.

У мовній свідомості письменника вітер постає як жива істота, яка має чуб: „Дзенькнула кобза на вітрі чубатім / В тиші, мов крига, німій” (т. 5, с. 100); пальці: „Замислившись, на палець собі вітер / Незчувсь, як павутину намотав” (т. 5, c. 136); губи: „Квіт на каштанах так чисто і юно зайнявсь, / Вітер волого припав до пелюсток губами...” (т. 1, с. 60). Bimер у мовній свідомості Б. Олійника - активний: він виконує дії, притаманні людині, серед яких такі: „Тільки вітер вміло вимуровує / У заметах замок зачарований” (т. 1, с. 32); „Вітер в кущах регоче: / - Мучтесь, коли — раби!” (т. 1, с. 84); „По дорозі мене вітер обганя: / Груди - колесом / А хмари - з-за халяв” (т. 1, с. 96); „Вітер з подиву спинився зоддалік. / Зміряв поглядом, всміхаючись незло: / — Щось ти, — каже, — чи не спутав / День за рік?/ Від учора вже... піввіку одгуло!” (т. 1, с. 96).

На позначення класифікації явищ природи атмосферні опади репрезентують різні пори року. Мовний образ зими створюється за допомогою снігу. Сніг є одним з неодмінних атрибутів зими. Проте Б. Олійник метафоризує сніг не як вид опадів, а як опис певних людських стосунків, зокрема між жінкою та чоловіком, порівн.: „Ще відчула, як руки його прослизнули під пахви / I пальці пожадно опали / На розпечений сніг нетерплячих грудей — i тоді...” (т. 1, с. 45); між матір'ю та сином: „Мати сіяла сніг, щоб він м'яко - до ніг, / А вродило зілля" (т. 4, с. 23). У метафорі актуалізується властивість снігу бути м'яким, тобто вираз , підстелити соломи”, моделювання якого базується на актуалізації паремії Знав би куди впаду, то соломки підстелив, Б. Олійник репрезентує у вигляді метафори "сніг”- це вербалізація теплого ставлення матері до сина. Привертає увагу й лексема "сіяти", що має етнокультурне підгрунтя: в українській обрядовості процес засівання символізує побажання здоров'я та щастя. Можна відзначити також специфіку вживання метафори у виразі загорівся сніг, де актуалізується сема “властивість кольору: сніг — біле тіло, маки - червона кров”, порівн.: „Загорівся сніг маками / Під грудьми у вояка” (т. 4, с. 32). Більш сталим для багатьох поетів $є$ репрезентація снігу у вигляді сивини, в основі чого покладена ознака кольору, саме зі снігом, бо він білий, але такий, що вже не розтане: „I першим снігом притрусило скроні, / Якому вже не тануть по весні” (т. 5, с.137).

Завірюха в мовно-поетичній площині Б. Олійника, на відміну від снігу, $\epsilon$ персоніфікованим образом, на який переносяться властивості та дії людини: „Скоро затужиться / Стужам на цілому світі” (т. 1, с. 89); „Так і тоді завірюха / Крутила вороже...” (т. 1, с. 94); „Раптом наїхали віхоли звихреним табуном!” (т. 1, с. 66); „А як піде з висвистом завірюха клята...” (т. 1, с. 106). Автор використовує цілий синонімічний ряд - завірюха, стужа, віхола, заметіль.

Словесно-художня реалізація реципієнтної сфери дощ есплікується на позначення сліз: „На цій горі, на пагорбі печалі, / Де все болить - від квітки до хреста, - Ідуть дощі вдовиними плачами...” (т. 3, с. 115); ,Загорнулась хмарою осінньою / I, затимавши в зіницях дощ, / Похитала головою сивою / Та пішла доварювати борщ” (т. 4, с. 43 ); надї: „Чистий дощ, як надія” (т. 5, с. 58); врожаю - „Пшеничний дощ” (т. 5, с. 58). Своєрідність дощу інколи виявляється дивним кольором самого дощу. У різних місцях світу в різний час відзначались кольорові атмосферні опади, в Б. Олійника жовтий дощ є вісником мору, явища 3 негативною семантикою, порівн.: „І падав на колиби жовтий дощ — / Безжальний вісник світового мору" (т. 6, с. 89).

\footnotetext{
${ }^{3}$ С. Я. Срмоленко, Мовно-естетичні знаки украйнської культури, Київ 2009, с. 275.
} 
Наступна реципієнтна сфера — це темрява. Емоційна реакція на темряву має важливе метафоричне значення в усіх культурах. У міфології темрява символізує зло, неосвіченість. У Християнстві темрява, на відміну від світла, образом якого є Ісус Христос, уособлює Диявола: „І тьма несвітня демоном звелася, / Згасивши вмить лампади і свічки" (т. 3, с. 148). На позначення цієї реципієнтної зони автор використовує синоніми - темрява, темінь, тьма, сутінь - 3 позитивною конотацією, порівн.: „І ховали останки темені / Двадцять сім воронених дул” (т. 3, с. 13); „Клубилася темінь” (т. 3, с. 80); „Спадала сутінь м'яко 3 далини” (т. 5, с. 144). У виразі „Нехай простять їх темноту боги” (т. 6, с. 19) темнота символізує неосвіченість і моделює смисли, негативно конотовані.

Мовно-художня репрезентація рецепієнтої сфери роса в поезії Б. Олійника порівнюється з людською сльозою: вона стає гіркою, солоною, пекучою, що виражає негативну конотацію, на відміну від міфопоетичних уявлень. Роса в міфопоетичних уявленнях має таке ж містичне значення, як у багатьох випадках вода: очищення, здоров'я, родючість. До того ж, уважається, що роса як явище має небесне походження - це „божа сльоза”. А з божої сльози виникає життя, народжуються люди, ростуть трави і збіжжя, порівн.: „Тільки світить роса, / Як остання сльоза, - За тобою” (т. 1, с. 82); „Усе в чеканні: спілі краплі рос” (т. 1, c. 105).

Лексема туман також належить до реципієнтної зони поетичної метафори. Поет ототожнює туман із ковдрою, моделюючи позитивну конотацю: „Я від ока чужого / Туманом осіннім укривсь" (т.1, с. 54); саваном - у цьому разі простежуємо негативну конотацію, порівн.: „Коли землю, як в саван, / Загорне вологий туман” (т. 2, с. 182).

У художньо-семантичній площині автора метафоризуються й назви інших явищ природи, зокрема хмари, веселка, тінь, зоря, тиша тощо.

Отже, мовно-поетична площина поетичних текстів Б. Олійника наповнена метафоричними конструкціями. На основі проаналізованих одиниць можна зробити висновки, що найбільш широко репрезентовано образ вітру, причому він моделюється як персоніфікований образ, а всі інші явища природи метафоризуються рідше і як культурно-марковані символи вербалізують переважно внутрішні переживання людини. 